\title{
The Reflection and Reconstruction of the Remand for Retrial in the Criminal Retrial Procedure
}

\author{
Rukeya Abudureyimu \\ The School of Law, Central University of Finance and Economics, Beijing, P. R. China
}

Email address:

rukeya87@126.com

\section{To cite this article:}

Rukeya Abudureyimu. The Reflection and Reconstruction of the Remand for Retrial in the Criminal Retrial Procedure. International Journal of Law and Society. Vol. 4, No. 2, 2021, pp. 94-99. doi: 10.11648/j.ijls.20210402.16

Received: April 9, 2021; Accepted: April 22, 2021; Published: May 8, 2021

\begin{abstract}
For quite a long period of time, the research on criminal trial procedures has mainly focused on the theory and practical issues of remand for retrial in the second-instance procedure, and the retrial procedure as a criminal special relief procedure is not paid enough attention. The special relief nature of the retrial procedure determines that the remand for retrial in the retrial procedure should have its own independent characteristics. However, in judicial practice, the remand for retrial in the second-instance procedure and remand for retrial in the retrial procedure are often mixed in application, which has led to an expansion of the application of remand for retrial. This will not only produce circulating trials, cause the decline of litigation efficiency, but also make it difficult to achieve the purpose of criminal retrial procedures. To solve the problems of the remand for retrial system in the criminal retrial procedure, the focus is to regulate and restrict the application of remand for retrial. Therefore, on the basis of analyzing and summarizing the case data of the remand for retrial in the retrial procedure in recent years, this article systematically reflects and discusses the remand for retrial system, and proposes a limited application model, in order to the remand for retrial system play its function without dissimilation.
\end{abstract}

Keywords: Retrial Procedure, Remand for Retrial, Limited Application

\section{Introduction}

The system of remand for retrial in criminal proceedings is a method of case adjudication which is the people's court at a higher level hears the case, and when a statutory situation arises, then makes a ruling to revoke the original judgment and remand the case to the original lower-level people's court for retrial. The remand retrial system exists in the second-instance procedure, the death penalty review procedure and the retrial procedure. The remand for retrial of criminal proceedings as a method of case trial has been discussed in the academic circle for a long time. Its research focuses mostly on remand for retrial in the second-instance procedure, and insufficient attention has been paid to remand for retrial in the retrial procedure. However, there are thorny problems in judicial practice of the remand for retrial in the criminal retrial procedure in our country.

Specifically, on the one hand, the rate of the remand for retrial in the criminal retrial procedure nationwide has increased year by year. It can be seen from Figure 1 that the rate of the remand for retrial in the criminal retrial procedure has increased from $4 \%$ in 2000 to $13.53 \%$, an increase of nearly 3.4 times [1]. Although the proportion has declined slightly in recent years, but compared with the previous point of view, but compared to before the overall average is at a high level of $9.81 \%$. By comparing Figure 1 and Figure 2, two graphs showing opposite trends, it is not difficult to see that the number of retrial cases nationwide has been decreasing year by year, and has maintained a low level in recent years. This reflects that the retrial procedure is strictly applied as a special relief procedure in criminal proceedings. However, as an exception of a method of case adjudication as an exception to the handling of retrial cases in the retrial procedure, the application rate of remand for retrial has shown an upward trend. This phenomenon is worthy of reflection.

On the other hand, in the practice of the retrial procedure, the remand for retrial has been repeatedly applied. For example, Xu Yibin and Dong Zhanlong's intentional injury case [2], which has gone through three times of the remand for retrial. From the first-instance judgment made by the Luquan District Court in 2001 to the Shijiazhuang Intermediate Court sent the case back to the Luquan District Court for a retrial for the third time in 2017. Finally, in April 2018, the Luquan 
District Court made judgment the same as the judgment in 2001. The case lasted for 17 years. From the above-mentioned cases, it can be seen that under the three times sent back for retrials by the Intermediate Court, makes the retrial case in the strange procedure circle of" retrial-first instance-second instance-retrial". This hinders there trial procedure giving full play to its due special relief function.

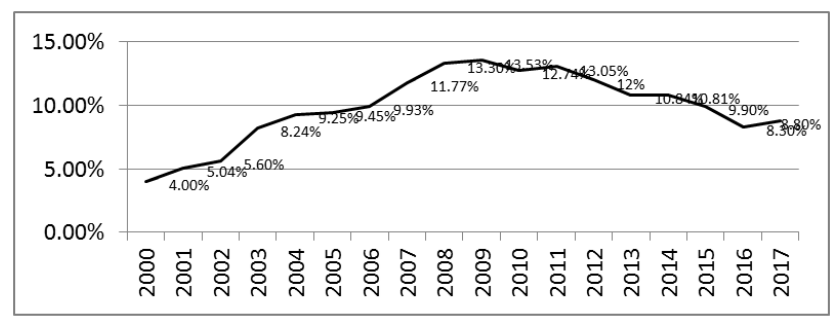

Figure 1. The Rate of the Remand for Retrial in the Criminal Retrial Procedure of China.

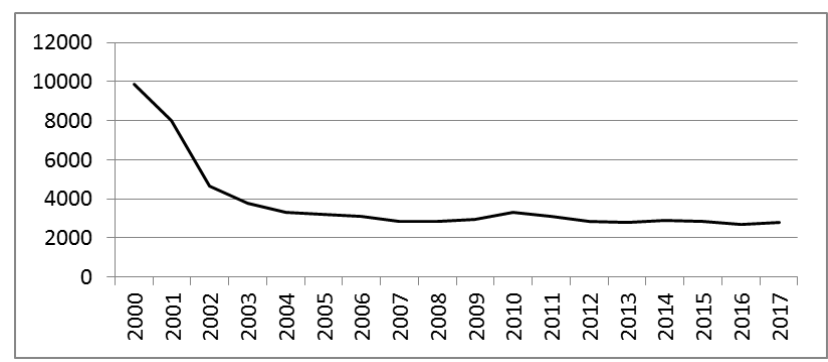

Figure 2. Statistics on the number of Retrial Cases Concluded in China.

The problems in practice need to be solved urgently, and it is necessary to systematically explore and study the system of the remand for retrial in the criminal retrial procedure. At present, the study is basically advocating the abolition of this system. There are opinions think that the retrial case should be finalized at first instance, and the facts are unclear, insufficient evidence of the case should be made a suspected acquittal [3]. This view is based on the consideration that the retrial procedure should adopt the first-instance final adjudication setting concept. It is believed that the remand for retrial system should not be applied. However, the application of the retrial system is the embodiment of a remedial function of the program refluxing, the two do not conflict. The remand for retrial can still have the final decision. There are also opinions think that the establishment of the retrial system is not in line with the value of procedural justice, conflicts with the legislative spirit of suspected crime, and violates the economic principle of litigation, and should be abolished [4]. This view generally negates the value meaning of the remand of retrial. In fact, it is precisely because of the special relief attribute of the retrial procedure that the remand of retrial in criminal retrial procedure has its own independent characteristics, and always serves the realization of the value of the retrial procedure.

Although there are disputes about the remand for retrial in the retrial procedure, it should not be abandoned. In fact, the legal system is based on the experience gained in the development of legal civilization and has as set of logical principles that are self-consistent and satisfactory [5]. On the one hand, the criminal procedure requires trial in time; on the other hand, it also requires the maintenance of judicial justice as much as possible. The criminal retrial procedure actually breaks the final rule under certain circumstances and obtains a balance of interests. Therefore, the retrial procedure is limited to an "extraordinary relief procedure" or "special relief procedure" in the legal systems of each country [6]. The particularity of the retrial procedure makes the remand of retrial have its independent characteristics and should be distinguished from the ordinary procedure of retrial. Based on this, this paper intends to reflect on the current situation of the remand of retrial, and to distinguish the remand of retrial in retrial procedure from the second-instance retrial, reflect its unique nature, and then, on the basis of a reasonable analysis of its special attributes, apply its limitation, in order to reflect the exceptional characteristics of its special procedures, so that it can play a role without dissimilation.

\section{The Status Quo and Reflection of Remand for Retrial in Criminal Retrial Cases}

\subsection{The Status Quo of Remand for Retrial in Criminal Retrial Cases}

\subsubsection{The Current Status of Judicial Practice in Retrials}

In practice, there is a phenomenon that the retrial court confuses the reasons for remand for retrial. Through the analysis of a large number of retrial judgment documents sent back for retrial, it is found that the main reasons for the retrial court to send back for retrial are "unclear facts and insufficient evidence", "procedural violation", "unclear facts, wrong application of law" and "error of application of law" and there are expressions such as "lawsuit procedures in violation of the law." According to the "Interpretation of the Supreme People's Court on the Application of the Criminal Procedure Law of the People's Republic of China", retrial cases can only be remanded for retrial when the facts are unclear or the evidence is insufficient. The reason for the confusion in the application of the reasons for remand for retrial is that the legal basis of remand for retrial in the second-instance procedure was applied.

In the past ten years, the average number of retrial cases sent back for retrial in China was about 331 (Figure 3). Based on this, the author collected a total of 300 retrial judgment documents issued by people's courts at all levels in recent years to investigate the legal basis cited in the court's retrial procedures. There are mainly three situations: citing alone the judicial interpretation of the Criminal Procedure Law on remand for retrial in the retrial procedure, citing alone the Criminal Procedure Law on remand for retrial in the second-instance procedure, or citing both at the same time (Figure 4). According to data analysis, it is not difficult to find that remand for retrial of retrial cases cited on the legal basis 
of the second-instance procedure accounted for an absolute majority. Due to the lack of effective restrictions on the exercise of the right to remand for retrial by the retrial court, the issue of the mixed application of the reason for remand for retrial in retrial cases has increased the reason for remand for retrial, which has been activated multiple times, making it more difficult to inhibit the retrial court's power to remand for retrial.

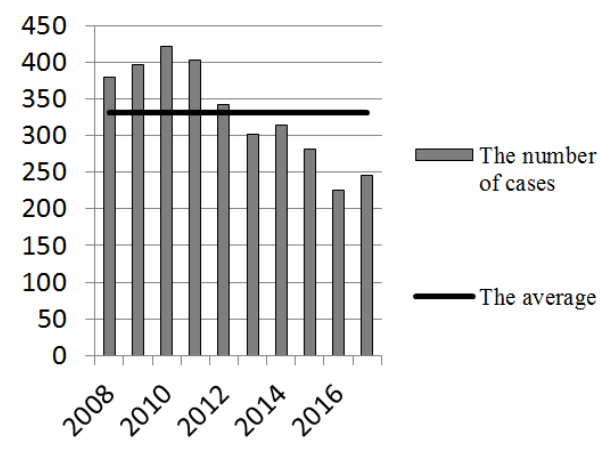

Figure 3. Retrial cases sent back retrial average statistics.

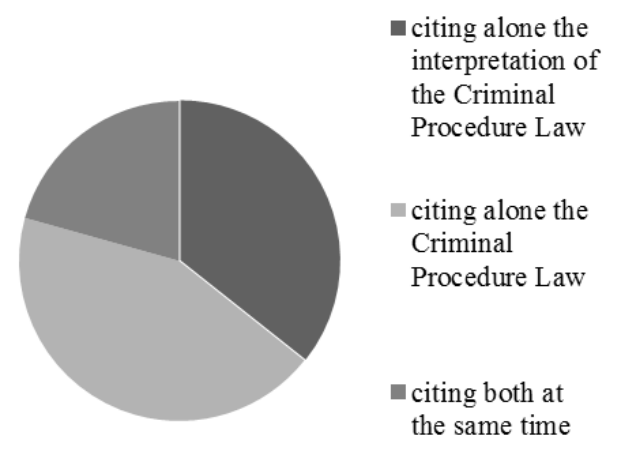

Figure 4. The legal basis for retrial cases to be sent back for retrial.

\subsubsection{The Status Quo of the Legal Provisions for Remand for Retrial in Retrial Proceeding}

The system of remand for retrial is not clearly stipulated in china's Criminal Procedure Law. The relevant provisions are reflected in the interpretation of the Law of Criminal Procedure, which only specified the "facts are unclear, insufficient evidence" as a kind of substantive cause of the situation, does not involve procedural violations. According to the "Summary of the National Symposium on Trial Supervision on a Number of Issues in the Current Trial Supervision Work " promulgated by the Supreme People's Court in November 2001, for cases retrialed in accordance with the procedures of second-instance, if the facts found in the original judgment are unclear, the evidence is insufficient, or other circumstances are remanded for retrial, the higher court may rule to revoke the original judgment and remand it to the original people' scour for retrial. Although the minutes of the Supreme People's Court do not have legal effect and cannot be cited as the basis for the court's decision, they are inherently binding on judges in judicial practice and play a guiding role in adjudication of cases to judges. The handling opinions in the minutes clearly defined the situation of "unclear facts and insufficient evidence" and that "other circumstances sent back for retrial" did not mean that if the original trials were procedural violations and the case could be sent back for retrial. Combined with the provisions of China's criminal procedure law, the necessary prerequisite for the commencement of retrial proceedings is that the effective judgment is "indeed wrong", including five specific scenarios: new evidence can prove that the facts established by the original trial judge were wrong; the evidence for conviction and sentencing is insufficient or contradictory; errors in application of law in the original trial procedure; violation of legal procedures, may affect fair trial and judges corruption and bribery, malpractices for personal gains, and perverted judgment. Judging from the above reasons for initiating the retrial procedure, the retrial procedure is mainly a relief to the substantive issues of the case, which is different from the consideration of both substantive and procedural issues in the second-instance procedure. There is also a view that it's no need to initiate a retrial in all "wrong" cases, which should mainly point to cases that have a real impact on the interests of the accused or the public interest [7]. Therefore, the "other circumstances sent back for retrial" in the minutes should be understood as a situation that affects the substantive issues of the case. From the perspective of legal provisions, the application of remand for retrial in retrial procedure and second-instance procedure is different in procedure.

In addition, according to the Criminal Procedure Law, criminal retrial cases in china are tried in accordance with the first instance procedure or the second instance procedure according to the trial level of the original trial court. However, this does not reflect that the retrial case has returned to the ordinary procedure. Its nature is still a trial supervision procedure. The "Opinions on Several Specific Procedures Concerning Criminal Retrial Work" issued by the Supreme People's Court on October 15, 2003 stipulates that cases that are remanded for retrial of effective judgments shall be re-trialed by the trial supervision court, and establish the penalty number "zai" (means again or re-) clarifies the retrial nature of such cases and cannot be equated with the ordinary procedure of second instance.

\subsection{The Reflection on the System of Remand for Retrial in Retrial Procedure}

\subsubsection{Harmful of the Remand for Retrial Is Repeatedly Applied}

Repeated remand for retrial will inevitably lead to the inefficiency of litigation and the substantial increase in litigation costs. Moreover, if the decision of the original trial after the retrial case is sent back for retrial is completely revoked, the effective judgment on which the penalty depends shall be lost in the basis of enforcement. It will leave the case in a state of uncertainty and sentence pending, even if the penalty has been executed. For the accused, the long-term detention and the pending decision, is also a serious complaint, which is also part of the inducement for overdue custody [8].

On the other hand, in the retrial proceedings, in cases where the court's judgement has had legal effect and the criminal prosecution proceedings initiated have been concluded, the 
court and the prosecution can initiate a retrial on the grounds that the judgement is "indeed wrong". The court could be the initiator of a new trial process or even the initiator of a new round of criminal prosecution [9]. The remand for retrial invalidated all previous prosecution proceedings that is the activity of re-opening the prosecution against the same act of the accused. The repeated activation of the remand for retrial has further deepened the degree of repeated prosecution of the defendant. Unrestricted error correction mechanism is bound to cause arbitrary criminal prosecution and the fictitious form of litigation. It can be seen that the repeated of remand for retrial keeps the case in a state of resolving disputes, and the defendant is in a state of being prosecuted, which ultimately leads to the expansion of the effectiveness of retrial remand. This not only causes the litigants to lose their reasonable expectations of judicial authority and the stability of rights relief, but also leads to the emergence of a crisis of the national criminal prosecution power arbitrarily exercised, which has an impact on china's judicial system.

\subsubsection{The Independent Nature of Remand for Retrial in Retrial Procedure}

The problems in the remand for retrial are not new problems. The reason why it is difficult to clarify is the mixed application of remand for retrial in retrial procedure and second-instance procedure resulting in the expansion of remand for retrial. However, remand for retrial in the retrial procedure, as a way of handling a retrial case after trial, has its own independent characteristics and should be distinguished from the second-instance procedure [10]. This is a necessary prerequisite to avoid the generalization of the retrial system.

(1) On the whole, remand for retrial is a decision made by a higher court on a case concluded by a lower court, but there is a fundamental difference between the retrial procedure and second instance procedure about the object of remand for retrial. Remand for retrial in retrial procedure denies the effective judgment of the original trial court. Whether the remand for retrial system should be applied to the remedy of the wrong effective judgment should depend on the balance between the stability of the law and the substantive justice. According to second trial final judgment system in china, an effective judgment has not yet been produced at the second instance. So the second-instance remand for retrial is a denial of the facts, laws, and procedural legality in the original trial, indicating that there was an error in the trial of the case. And whether the remedy for the trial error should be remanded for retrial, it depends on the requirements of trial-level supervision and correct and fair trial. Based on this, the particularity of the subject of remand for retrial in retrial procedure requires a distinction between retrial and the second-instance procedure in the system setting.

(2) The feature of retrial is that it breaks through the authority of the judgment and the stability of the procedure. It is a special remedy for the retrial of the wrong effective judgment, which is different from the ordinary remedy of the second-instance procedure. The relief function of the second-instance procedure focuses on protecting the litigant's right of appeal, urging the proper exercise of the first-instance judgment, and enhancing the acceptability of judicial judgments. The retrial procedure focuses more on the relief of wrong judgments and maintains the uniform implementation of the law. That is: the second-instance procedure takes into account both substantive and procedural remedies, and the retrial procedure is mainly remedies for substantive content. The particularity of the remedial function of the retrial procedure inevitably requires that the remand for retrial run within its own normative system and institutional framework, and cannot cross the limit at will. Therefore, the remand for retrial system in the retrial procedure should be strictly limited in the setting of specific reasons, and it should be distinguished from the ordinary second-instance procedure.

\section{Reconstruction Path for Remand for Retrial in Criminal Retrial Procedure}

The principle of prohibition of double danger be followed by the retrial procedure is based on the reasonable suppression of the entity-reality of the criminal litigation to promote the realization of the value of the litigation [11]. And the reconstruction of the remand for retrial system in criminal retrial procedure should be reasonably restricted on the basis of being separated from the remand for retrial in the second instance procedure system.

\subsection{Redefine the Reasons for Remand for Retrial in Retrial Procedure}

The judicial interpretation of criminal proceedings in my country clearly stipulates the substantive reasons for remand for retrial of criminal retrial cases with "unclear facts and insufficient evidence", and adopts optional clause pattern. It can be seen that judge's power of discretion has the absolute advantage in remand for retrial. Therefore, combined with the independent characteristics of remand for retrial, the reasons for remand for retrial shall be restricted and refined.

Case facts are not facts that actually happened in a historical case, but factual statements presented to the court by the accused and the defendant and other litigation participants based on the facts of the case [12]. Since the facts of the case presented as statements are intercepted or framed and submitted to the court for trial, it is inevitable that the judge will make a negative affirmation based on the facts of the case during the trial, that is, it is deemed as "unclear facts." On the other hand, the determination of the facts of a case relies on or is subject to evidence, and the judge needs to analyze and judge the evidence to determine the facts of the case. However, due to the difference in the distance between the evidence and the facts of the case, the degree of closeness, and the degree of validity of the proof, especially the different powers to prove the main facts of the case, there will be cases of unclear or wrong fact identification in trial practice. Insufficient evidence and improper certification of evidence lead to errors in ascertaining facts. There are opinions think that the judge's foresight was biased, which led to the wrong factual 
determination [13]. However, regardless of whether the qualitative determination or the fact determination is wrong, in view of the retrial review as the pre-procedure of the retrial trial, the facts and evidence issues of the case should be fully reviewed and evaluated. Therefore, the retrial court can directly make corrections. It is difficult for the retrial and remand to play the remedy function of substantive matters in the aspect of fact finding. In accordance with the clear provisions and requirements of the law, judges in the face of insufficient evidence cases, should directly invoke the express provisions of the law to make a not guilty verdict against the crime is not established [14].

However, unclear facts and insufficient evidence in retrial cases cannot be generalized. The procuratorate will also make mistakes in the prosecution, and the court will make corresponding judgments on the basis of the mistakes. This has caused disagreements in understanding. The prosecutors must withdraw the prosecution to correct the errors. In view of the provisions of Chinese law, the prosecutors can withdraw the prosecution before the effective judgment is made. Therefore, during the retrial, the procuratorate filed a protest and then applied for withdrawal. The retrial court needs to revoke the original judgment and remand it for retrial, support to the procuratorate for error correction.

This article believes that reasons for remand for retrial in criminal retrial procedure are only applicable to situations where the procuratorate protests and requests to withdraw the prosecution. In addition, retrial cases cannot be revoked or remanded on the reason of "unclear facts and insufficient evidence". The cases shall be conducted directly by the retrial court.

\subsection{Limitation Applies of Remand for Retrial in Retrial Procedure}

Based on the principle of ensuring the neutrality of the court's trial to the maximum extent and maintaining the concept of "passive justice", the court should uphold the principle of modestly restriction [15]. At present, there are courts, procuratorates, litigants and their legal representatives, and close relatives as the subjects of initiation in retrial system of china. The trial mode is conducted in accordance with the first-instance procedure or the second-instance procedure. Therefore, the complete construction of remand for retrial needs to be considered in terms of the initiation of retrial, trial procedures, in order to realize the system limitation of remand for retrial in retrial procedure.

(1) Retrial cases initiated by the court should not be sent back for retrial. Current criminal procedure law clearly stipulates that the presidents of the people's courts at all levels, the Supreme People's Court, and the higher people's courts can take the initiative to initiate retrial procedures to correct errors if they find that the effective judgment is indeed wrong. The court is the judge of criminal cases and the proposer of the criminal prosecution procedure. Even if it is aimed at "correcting all errors" and guaranteeing the objectivity and impartiality of criminal cases, the court's self-initiated retrial procedure not only makes judges preconceived and subjective assumptions become possible, and the defendant is once again placed in prosecution proceedings. This kind of prosecution is different from the prosecution of the procuratorate, which requires court review, and the court's initiative to initiate retrial puts the court in a position to examine and judge by itself, which is not conducive to the protection of the rights and interests of the defendant. If the retrial court sends the case back for retrial, then the court once again becomes a criminal prosecutor and the defendant is trapped in repeated prosecutions. This shows the prosecution tendency of the court as a judicial organ. Therefore, even if the court is to achieve self-correction and the superior court's function of supervising the trial of the lower courts, however, at the expense of the defendant's basic rights and interests, violates the value goal of criminal procedure law.

(2) Cases that have been ordered for retrial shall not be sent back for retrial. The 2012 Criminal Procedure Law revised the jurisdictional model of retrial, stating that unless it is more appropriate to order the original trial court to retry, the case that the higher court orders retrial must be ordered to be tried by a people's court other than the original trial court. Accordingly, the circumstances under which the retrial instructed by the original people's court should be used as an exception, and the principle of retrial in another place should be the principle. The order for retrial at a different place is reflected in the higher-level people's court instructing a lower-level people's court that has no legal jurisdiction to retry the case. If the system of remand for retrial is applied in the case of a retrial in another place, it will be impossible to determine the remand to the court for retrial. On the one hand, the original court cannot accept the case due to the lack of the basic characteristics of remand for retrial. That is, remand for retrial means that the higher-level people's court sends the case back to the lower-level people's court for trial. There is no subordinate relationship; on the other hand, the lower court of the retrial court cannot accept the case due to lack of legal jurisdiction over the case. Therefore, ordering retrials in different places can make the retrials more objective and fair, but the combination with the remand for retrial system will make the case stuck in a dilemma.

(3) Restrictions on retrial cases concluded in the second instance to be returned for retrial. In the criminal retrial procedure, the application of remand for retrial for cases concluded in the second instance is complicated to a certain extent.

First of all, if the original court of second-instance procedure has remanded the case for retrial in the ordinary procedure, can it be remanded for retrial in the retrial procedure? The 2012 revision of the Criminal Procedure Law imposed a limit on the number of retrials in the second-instance procedure to protect the basic rights of the defendant and improve the efficiency of 
litigation. Similarly, the system of remand for retrial in the retrial procedure should be limited to one time. This is not only the basis for restricting the generation of circular trials, but also a direct guarantee for the judicial power of the retrial court. It also indirectly protects the court's prudence and caution in ordinary procedures. Therefore, since the same case has been remanded for retrial, both in the ordinary procedure and in the retrial procedure, the opportunity to remedy the trial error has been fully obtained. Therefore, it cannot be remanded for retrial, otherwise it will not only cause the infringement of judicial resources necessary waste, will also hinder the protection of the rights of the defendant and the realization of the value of litigation benefits.

Secondly, the original court of first-instance did not make any mistakes in the retrial cases which concluded in the second-instance, but the original court of second-instance had errors that seriously affected the correct judgment of the case, and the remand for retrial system should not be applied. If the case is sent back for retrial, it means that the second-instance court's mistakes will be borne by the first-instance court, which not only goes against the principle of the court's own responsibility, but also increases the trial grade invisibly and increases the litigation burden on the accused. Therefore, the retrial court should try and make a judgment in the correct second-instance procedure, and cannot remand it for retrial.

Finally, under the premise of being cautious, diligent, and in good faith, judges still face the possibility of errors in the determination of facts and the application of laws in specific cases. This is one of the inherent attributes of justice [16]. The system of remand for retrial should be an approach for court to correct judicial errors, not a punishment for the litigants. Therefore, the litigants should be given the right to choose whether to remand for retrial. When disagree to send the case back for retrial, the retrial court should made direct judgments which has procedural justice for the litigants.

\section{Conclusion}

Different from the system of remand for retrial in the second- instance of criminal proceedings in china, the Criminal Procedure Law does not clearly stipulate the system and norms of remand for retrial in retrial procedure. In the judicial practice of retrial cases, the remand retrial system of the second-instance procedure is completely applied, ignoring the special attributes of the retrial procedure, which makes it difficult to realize the finality of the procedure. As a special relief procedure, the criminal retrial procedure maintains the finality and stability of court judgments. In the final analysis, it should reflect the protection of the value of litigation. The remand for retrial of retrial cases is a secondary impact on the effective judgment, and the system should be set in accordance with the interests of the litigants. The limited application mode of remand for retrial in retrial procedure is the core content of restructuring the remand for retrial system. As a result, it is possible to clarify the boundaries between remand for retrial in the second- instance and the criminal retrial procedure, and outline the basic content of the remand for retrial system, that is, remand for retrial of retrial cases should be applied as a special form of judgment. Only in this way can the functions of the remand for retrial system which cannot be replaced by maintaining the original judgment and changing the judgment be brought into play.

\section{References}

[1] The data for this article are derived from a statistical analysis of the statistical tables in the Law Yearbook of China on the number of retrial cases heard by courts nationwide in 2000-2018.

[2] Criminal Judgment of the Luquan District People's Court of Shijiazhuang City, Hebei Province (2018) Ji-0110-Xing-Zai-1.

[3] Cheng Xiangpeng. A Monograph on criminal retrial procedure [M], China University of Political Science and Law Press, 2018.

[4] Gu Xiaofang. Research on the system of retrial in criminal retrial [D], Southwest University of Political Science and Law, 2014.

[5] Cheng Weidong (editor-in-chief). The theory of criminal procedure system [M], China Legal System Publishing House, 2011.

[6] Chu Dianqin. Re-exploration of the function of criminal retrial system-also on the amendment of china "Criminal Procedure Law" [J], Shanghai University Journal (Social Sciences Edition), 2014 (01): 56.

[7] Jiang Bixin. The concept, policy and mechanism of criminal ltrial [M], People's Court Press, 2019.

[8] Ma Kang. The study on the system of criminal retrial — the analysis of duty crime cases [J], Journal of Railway Police College, 2020 (01): 82.

[9] Chen Ruihua. Problems and doctrine in criminal procedure [M], China Renmin University Press 2011.

[10] Li Xiaoxiao. The independent characteristics and double limitation mode of civil retrial procedure [J], Jurist, 2016 (03): 105.

[11] Wang Minyuan. Criminal Procedure Law [M], Intellectual Property Press, 2013.

[12] Guo Hua. Methods of confirming case facts [M], China People's Public Security University Press, 2009.

[13] Shi Lin. Amendment and control of the Judge'spre-see bias in the facts of the case [J], Law and Business Research, 2018 (04): 71 .

[14] Guo Hua. Theoretical review and rule restatement of no punishment for doubtful [J], Tribune of Political Science and Law, 2021 (01): 164.

[15] Li Ci. Research on the way to start the criminal retrial procedure in china [J], Jiangxi Social Sciences, $2015(03)$.

[16] Chen Ke. Discussion on the possibility of error injustice [J], Law Science, 2020 (12): 80. 